Nr 1(70), 2021, s. 43-56

https://doi.org/10.12797/Politeja.18.2021.70.04

\title{
Katarzyna JĘDRASZCZYK (D)
}

Uniwersytet im. Adama Mickiewicza w Poznaniu

jedra@amu.edu.pl

\section{MODELE PAMIĘCI O HOLOKAUŚCIE NA UKRAINIE W KONTEKŚCIE MARGINALNOŚCI I MARGINALIZACJI DYSKURSÓW PAMIĘCI}

ABSTRACT Models of Memory about the Holokaust in Ukraine in the Context of Marginality and Marginalization of Memory Discourse

There are two main models of memory in Ukraine: nationalist and post-Soviet. After 1991, Ukrainian historiography concerning the Holokaust was influenced by Soviet and emigration historiography. It was reactive to the allegations that the Ukrainians are anti-Semitic. In the nationalist model of memory, there is no space for the memory of the Holokaust in Ukraine, it is rather a strategy of displacing trauma and guilt or emphasizing the contribution of Ukrainians to saving Jews. The post-Soviet model also goes without a narrative about the Holokaust, but rather because of the lack of tradition in the USSR of describing war as a multi-ethnic experience. In this sense, both models are similar - both are mono-ethnic narratives. The minority discourse (ethnic model) about the Holokaust in Ukraine has not yet advanced to the rank of a nationwide narrative.

Keywords: Holocaust, Ukraine, memory, narratives, historiography, memory politics, post-memory

Słowa kluczowe: Holokaust, Ukraina, pamięć, narracje, historiografia, polityka historyczna, postpamięć 
Marginalność i marginalizacja dyskursów pamięci są ściśle związane z mechanizmami zapominania i wypierania. Przyczyną marginalności może być nieduży zakres czy małe znaczenie zdarzeń oraz nieświadome niedocenienie ich przez współcześnie żyjących ludzi. Marginalizacja wiąże się natomiast $\mathrm{z}$ intencją uczynienia zdarzenia mało znaczącym, choć z punktu widzenia kultury pamięci nie powinno to być może mieć miejsca. Jeśli przyjmiemy tezę, że temat Holokaustu nie jest wystarczająco wyraźnie obecny na Ukrainie, pojawia się pytanie o źródła tego zjawiska w kontekście marginalności i marginalizacji oraz modeli pamięci i polityki historycznej.

\section{O MECHANIZMACH ZBIOROWEJ AMNEZJI I MODELACH NARRACJI}

Holokaust i II wojna światowa są w Europie traktowane jako podstawa pamięci europejskiej - część przeszłości, która podlegała unaradawianiu i uniwersalizowaniu. Okazuje się jednak, że dla poszczególnych krajów charakterystyczne są określone motywy przewodnie i strategie postępowania wobec pamięci o Holokauście ${ }^{1}$. Trudno doszukiwać się podobieństw np. w polskiej i ukraińskiej pamięci historycznej o Żydach². W Polsce temat ten jest bardzo silnie włączony w nurt pamięci o II wojnie światowej, w wypadku Ukrainy i Białorusi - proces ten znajduje się w fazie początkowej ${ }^{3} \mathrm{i}$ trudno przewidzieć, jak się potoczy.

Można przyjąć, że na Ukrainie funkcjonują dwa główne modele pamięci ${ }^{4}$ (narracje pamięci $\left.i^{5}\right)$ - nacjonalistyczny/narodowy/ukraiński i postradziecki ${ }^{6}$. Pierwszy wiąże się $\mathrm{z}$ etnocentryzmem oraz natywizmem (rozumianym jako świadome dążenie członków społeczeństwa do odnowy lub uwiecznienia wybranych aspektów własnej kultury). Wyróżnikiem tej narracji są opis opresyjności, jakiej doświadczyli Ukraińcy ze strony

1 R. Chwedoruk, Polityka historyczna w Europie - periodyzacja i wiodace dyskursy, „Studia Politologiczne" 2015, vol. 35, s. 63-64.

2 M. Kawa, Narracje o Holokauście. Dyskurs naukowy a debata publiczna w Polsce, Chełm 2017.

3 Na temat cech wspólnych i różnic w recepcji Zagłady w całej postkomunistycznej Europie zob. J.P. Himka, The Reception of the Holokaust in Postcommunist Ukraine, [w:] Bringing the Dark Past to Light. The Reception of the Holokaust in Postcommunist Europe, red. J.P. Himka, J.B. Michlic, LincolnLondon 2013. Joanna B. Michlic wyodrębniła trzy istotne wymiary: „pamiętanie dla upamiętnienia”, „pamiętanie dla korzyści” oraz „pamiętanie, żeby dać spokój/zapomnieć”. Zob. J.B. Michlic, „Pamiętanie dla upamiętnienia”, "pamiętanie dla korzyści" i "pamiętanie, żeby zapomnieć". Różne modele pamięci o Żydach i Zagtadzie w postkomunistycznej Polsce, „Kultura i Społeczeństwo” 2011, vol. 55, nr 4.

4 Modelami pamięci historycznej zajmowali się na Ukrainie m.in. W. Krywoszeja, H. Kasjanow. Szerzej: В. Кривошея, Моделі пам'sті і державна політика пам'sті, „Національна та історична пам'ять” 2011, Вип. 1, s. 26-37; Г. Касьянов, К проблеме дефиниций: историческая память, историческая политика, [w:] Г. Касьянов, О. Гайдай, Історія, пам'ять, політика. Збірник наукових статей, упоряд. Київ 2016, s. 125-126, Г. Касьянов, Past Continuous: Icmoрична політика 1980-x-2000-x: Укарїна та сусиди, Київ 2018.

5 Rozumiane jako współwystępowanie obrazów i tekstów, przewidujące prowadzenie opowieści (narracji) na temat przeszłości.

6 Modele o mniejszym zasięgu i znaczeniu - imperialny (widoczny jest np. w Odessie) i etniczne (właściwe dla grup narodowych czy etnicznych, innych niż naród tytularny i rosyjski). 
innych narodów, historia walki o niepodległość Ukrainy oraz umiejscowienie swego narodu w pozycji ofiary. Model postradziecki ma swe źródło w historiografii radzieckiej bądź późniejszej, ale wyrastającej z tej tradycji metodologicznej. Oba modele pamięci mają charakter ekskluzywny za sprawą wykluczenia z kolektywnej pamięci historycznej elementów, które przeszkadzają w kształtowaniu jednego jej wariantu. Uprawnione jest zatem pytanie (na które poniższa odpowiedź będzie zapewne jedynie wyznaczeniem ram dla rozważań), czy w tych modelach znajduje się przestrzeń dla rzetelnego dyskursu o losach Żydów ukraińskich w czasie II wojny światowej.

Częstym przejawem selektywnego zapominania jest tzw. filtrowanie pamięci ${ }^{7}$, polegające na wybieraniu pewnych fragmentów pamięci, a przemilczaniu czy wręcz wykreślaniu innych - niewygodnych (np. kolonializmu, faszyzmu czy komunizmu). Główną funkcją pamięci jest utrzymywanie spójności, dlatego fakty, które nie pasują do obrazu, nie są rejestrowane. Paul Ricoeur mówił o zjawisku zapominania i złego używania historii, wiążąc zbiorową amnezję z pozbywaniem się złych wspomnień, by poradzić sobie z tą częścią przeszłości, o której narody chcą zapomnieć. Może to prowadzić do zniekształcenia i zakłamywania przeszłości. Według Ricoeura cztonkowie niemal każdej wspólnoty zawieraja niewypowiedziane porozumienie dotyczace tego, czego nie chca pamiętać. A to oznacza, że znajbardziej wstydliwych doświadczeń mogtaby nie ptynać żadna nauka na przysztośs ${ }^{8}$. Jak pisze Marian Golka: Zapomnieniem (czy niepamięcia) jest wszystko to, co mieści się poza spoteczna świadomością cztonków grupy. Takie zjawiska są z pewnością obecne także w ukraińskiej pamięci o Żydach.

\section{SOWIECKA HISTORIOGRAFIA A WSPÓŁCZESNY STOSUNEK DO ZBRODNI NA ŻYDACH}

Losy Żydów w Europie Wschodniej zazwyczaj układały się w jeden z trzech scenariuszy. Część Żydów znalazła się pod władzą nazistów, co zakończyło się eksterminacją, część brała udział w walce z III Rzeszą i jej sojusznikami w szeregach Armii Czerwonej lub $\mathrm{w}$ formacjach partyzanckich. Trzecia grupa zdołała uciec lub była deportowana za linię frontu wschodniego.

W radzieckiej historiografii tzw. Wielka Wojna Ojczyźniana zajmuje bardzo ważne miejsce. Na ten temat powstało w ZSRR prawdopodobnie około 20000 prac, ale do czasów pierestrojki nie używano w nich określania „Holokaust” ${ }^{10}$. W miejscach opisu zbrodni nazistowskich na Żydach pojawiały się pojęcia uogólniające: „ludność cywil-

M. Kula, Nośniki pamięci historycznej, Warszawa 2002, s. 55; tenże, Między przesztościa a przysztościa. O pamięci, zapominaniu i przewidywaniu, Poznań 2004; tenże, Amnezja - choroba tylko częściowo zawiniona, [w:] Wobec przesztości. Pamięć przesztości jako element kultury wspótczesnej, red. A. Szpociński, Warszawa 2005.

8 J. Żakowski, Rewanż pamięci, Warszawa 2002, s. 47; P. Ricœur, Pamięć, historia, zapomnienie, przeł. J. Margański, Kraków 2006.

9 M. Golka, Pamię́ spoteczna i jej implanty, Warszawa 2009, s. 145.

10 Ф. Аевітас, Голокост: пам'ять, факти, документи, [w:] Культура історичної памяті: європейський та український досвід, За реА. Юрія Шаповала, Київ 2013, с. 170. 
na”, „cywilni mieszkańcy”. Nie wolno też było informować o skali masowych mordów dokonywanych przez Niemców na Żydach ${ }^{11}$. Stalin nie tyle obawiał się współczucia dla ofiar Holokaustu, co chciał stworzyć obraz, w którym główną ofiarą wojny byłby cały „naród radziecki”, bez wyróżniania żadnej grupy etnicznej czy narodowej ${ }^{12}$. Tymczasem do aktów antysemickich dochodziło w wielu miejscach ZSRR, także z dala od linii frontów. Fala uchodźców żydowskich przyczyniła się do powstania mitu, że Żydzi są tchórzliwi, wolą się ukrywać, by dalej prowadzić interesy, i nie chcą bronić ojczyzny ${ }^{13}$. Powstało nawet pogardliwe określenie dla Żydów, którzy znaleźli się w Azji Środkowej - „taszkiencka armia”.

Ukraińska Socjalistyczna Republika Radziecka także funkcjonowała w atmosferze niechęci do Żydów. Nagonki na „trockistów”, „lekarzy-trucicieli”, „szkodników”, „imperialistów" i „syjonistów” uniemożliwiały rzetelne badania nad Holokaustem, choć czasem trudno było przykryć faktyczne zasługi narodu żydowskiego dla kultury, nauki i obrony kraju w czasie wojny. Według danych przytoczonych przez Feliksa Lewitasa 150 Żydów otrzymało wysokie odznaczenie wojenne - Order Bohatera Związku Radzieckiego - z czego 72 było urodzonych na Ukrainie. 27 nagrodzonych wysokimi odznaczeniami otrzymało je za forsowanie Dniepru i wyzwalanie Ukrainy ${ }^{14}$.

Sytuacji nie zmieniła „odwilż” i działalność szestydiesiatnyków. Rezonans społeczny wywołał jedynie wiersz-requiem Babi Jar rosyjskiego poety Jewgienija Jewtuszenki, utwory Bułata Okudżawy, Dmitrija Szostakowicza.

Okres Breżniewowski i „doktryna” socjalistycznego internacjonalizmu oznaczała walkę z syjonizmem. W literaturze historycznej nie brakowało prób falsyfikacji imion i nazwisk, by zatrzeć obco brzmiące dane lub zataić pochodzenie bohaterów czy naukowców. Wojna sześciodniowa wprawdzie moralnie podniosła radzieckich Żydów, ale jednocześnie jej efektem była kolejna fala emigracji do Izraela. Tworzony przez Breżniewa „kult” zwycięstwa w Wielkiej Wojnie Ojczyźnianej spowodował zmarginalizowanie nieśmiało pojawiających się w okresie „odwilży” narracji wspomnieniowych i alternatywnych opowieści o wojnie na rzecz metanarracji o zwycięstwie narodu radzieckiego.

11 W literaturze wskazuje się najczęściej liczbę ofiar wśród ludności żydowskiej na Ukrainie na 1,41,6 mln. Trudności w oszacowaniu liczby wiążą się także z określeniem obszaru, z którego pochodzity ofiary - w granicach USRR sprzed wojny czy po 1945 r. Zob. С. Кульчицький, Голодомор в Україні й украӥнський Голокост, „Голокост і сучасність. Науковий часопис Українського центру вивчення історії Голокосту" 2008, nr 1(3).

12 Stalin w sposób szczególny marginalizował Żydów. Niektóre narody, jak np. Gruzinów, Ukraińców, jednak uwzględniano w narracji. Narracja tworzona przez Żydów ma inaczej rozłożone punkty ciężkości. Podkreśla się, że tylko Żydów i Romów zabijano z powodów etnicznych, Ф. Аевітас, Голокост..., s. 171.

13 A. Lustiger, Czerwona ksiega. Stalin i Żydzi. Tragiczna historia Żydowskiego Komitetu Antyfaszystowskiego i radzieckich Żydów, przeł. E. Kaźmierczak, W. Leder, Warszawa 2004.

14 Ф. Аевітас, Голокост..., s. 171. 


\section{TEMATYKA HOLOKAUSTU W BADANIACH UKRAIŃSKICH PO 1991 R. A POLITYKA HISTORYCZNA}

Powstanie niepodległej Ukrainy spowodowało wydzielenie się „ukraińskiej szkoły” badań nad Holokaustem ${ }^{15}$. Choć publikacji na temat Żydów na Ukrainie przybywało ${ }^{16}$, badania nad Holokaustem po dziesięciu latach niepodległości nadal kształtowały się pod wpływem spuścizny intelektualnej odziedziczonej po nauce radzieckiej i ukraińskiej historiografii emigracyjnej, co paradoksalnie oznaczało w obu przypadkach reaktywność opisu. Badano zatem w pierwszej kolejności tylko te obszary, które wymagały odpowiedzi na zarzut o antysemityzm narodu ukraińskiego i mogły być wykorzystane dla polityki historycznej ${ }^{17}$.

Dla historyków ukraińskich zajmujących się II wojną światową problem Holokaustu, antysemityzmu i kolaboracji jest szczególnie trudny, oznacza bowiem konieczność zaprzeczania narodowym mitom wykreowanym w okresie sowieckim, ale równocześnie ryzykowanie grzechem „skalania własnego gniazda” i naruszenia komfortu psychicznego współobywateli. Budzi naturalną chęć prostowania lub przemilczania informacji o kolaboracji i antysemityzmie jako znacznie przesadzonych. Nawet w tekstach, które wydają się kompetentnie opisywać mechanizm rugowania z pamięci historycznej Holokaustu na Ukrainie przez władzę komunistyczną i wyjaśniać nieprawdziwość mitów, że „Żydzi zasłużyli sobie na nieprzychylność Ukraińców”, brakuje wzmianek o roli ludności cywilnej oraz formacji kolaborujących z Niemcami w eksterminacji Żydów. Akcent kładzie się na pomoc Żydom udzielaną przez sąsiadów i niektóre grupy partyzantów $\mathrm{UPA}^{18}$. W historiografii stosowane są zatem strategie radzenia sobie z traumą przeszłości wymienione przez Aleidę Assmann ${ }^{19}$.

Odejście od marginalizacji tematu możliwe jest poprzez dyskurs otwarcie przyznający, że pewna część ukraińskiego społeczeństwa rzeczywiście współpracowała z Niemcami i pomagała w eksterminacji Żydów ${ }^{20}$. Feliks Lewitas próbował odpowiedzieć na pytanie o źródła niechęci do podejmowania na Ukrainie tematu prześladowań

15 Szerzeј: А. Подольський, Тема Голокосту в сучасній українській історіографї̈: проблеми наукових досліджень та інтерпретаиій, [w:] Аруга світова війна і доля народів України: Матеріали Всеукраїнської наукової конферениї, Київ 2005, s. 32-34; Е. Иванова, Конструирование коллективной памяти о Холокосте в Украине, „Аb Imperio” 2004, nr 2.

16 Я. Калакура, Украӥнська історіографія, Київ 2004; Політична історія України 20 столітmя, m. 4. Україна в роки Аругої світової війни (1939-1945), Київ 2003; Україна: політична історія 20 - початок 21 столітms, Київ 2007.

17 J. Hrycak, Stosunki ukraińsko-żydowskie w postradzieckiej historiografii ukraińskiej, [w:] Historycy polscy i ukrainscy wobec problemów XX wieku, red. P. Kosiewski, G. Motyka, Kraków 2000, s. 104.

18 Ф. Аевітас, Голокост..., s. 175-176.

19 Najczęstsze z nich to kompensacja, eksternalizacja pamięci, wyłączanie, milczenie i przeinaczanie. Zob. A. Assmann, Pięć strategii wypierania ze świadomości, przeł. A. Pełka, [w:] Pamięć zbiorowa i kulturowa. Wspótczesna perspektywa niemiecka, red. M. Saryusz-Wolska, Warszawa 2009, s. 333-348.

20 Tematami, które należy zbadać i dopuścić do społecznej debaty, są m.in. kwestie związane z udziałem Ukraińców w tzw. policji pomocniczej, propagandą wokół określenia „żydokomuna” i jej skutkami dla stosunku do ludności żydowskiej, tzw. dniami Petlury i pogromami żydowskimi we Lwowie. 
i eksterminacji Żydów. Jego rozważania koncentrują się wokół trzech mitów, związanych z relacjami ukraińsko-żydowskimi: 1) Żydzi byli winni szerzeniu bolszewizmu i prezentowali wrogi stosunek do państwa ukraińskiego w latach 1917-1921;2) Żydzi byli organizatorami represyjnej machiny zwalczającej Ukraińców; 3) Żydzi byli współwinni wywołania głodu na Ukrainie 1932-1933 i dlatego doświadczyli przemocy nie tylko ze strony nazistów, ale i miejscowej ludności. $Z$ tymi stwierdzeniami łatwo się rozprawić, a przynajmniej ukazać ich relatywność, jednak dają one nadal podłoże do postaw antysemickich oraz marginalizacji tematyki żydowskiej przez środowiska związane z modelem narodowym/nacjonalistycznym ${ }^{21}$.

Wydawało się, że przełomem w wyznaczaniu nowych ram pamięci będzie przemówienie przewodniczącego Rady Najwyższej Ukrainy Leonida Krawczuka we wrześniu 1991 r. w Babim Jarze, w którym stwierdził, iż za zagładę Żydów odpowiedzialni są Niemcy, ale wszyscy są współwinni z powodu niezatrzymania oprawców. Leonid Krawczuk już jako prezydent niepodległej Ukrainy odnosił się do tematyki Holokaustu jedynie symbolicznie. Podobnie tematu unikał Leonid Kuczma - uczestnicząc w 60. rocznicy zbrodni w Babim Jarze (2001), zastosował retorykę postradziecką, nadal bowiem nie wyróżnił Żydów wśród ofiar.

Prezydent Juszczenko wraz z powołanym przez niego Ukraińskim Instytutem Pamięci Narodowej posługiwał się narracją narodowo-nacjonalistyczną. Zaproponował odejście od radzieckiego sformułowania „Wielka Wojna Ojczyźniana” na rzecz uniwersalnego dla Europy określenia „II wojna światowa”, kwestionował datę i znaczenie tzw. dnia zwycięstwa, konieczność organizowania defilad z okazji rocznic zakończenia wojny. Jako pierwszy prezydent tak wyraźnie zaczął używać określenia „Holokaust”. Kontekst w tym wypadku był jednak spójny z wizją etnicznej historii Ukraińców ${ }^{22}$. Wraz z dyskusją na temat tzw. Wielkiego Głodu lat 1932-1933, zainicjowaną przez środowisko polityczne prezydenta, pojawiała się tendencja do porównywania Hołodomoru z Holokaustem i nazywania Głodu „ukraińskim Holokaustem” albo „Holokaustem narodu ukraińskiego". Uzasadnieniem dla tego typu retoryki była próba dowiedzenia, że Głód podobnie jak Holokaust, był działaniem obliczonym na eksterminację całych narodów. Prezydent dążył do umiędzynarodowienia pamięci o Głodzie ${ }^{23}$ i uczynienia z niego uniwersalnego dla wszystkich Ukraińców odniesienia do przeszłości, na którym można budować tożsamość historyczną narodu ${ }^{24}$. Efektem mieszania tych pojęć i mo-

21 Ф. Аевітас, Голокост..., s. 167-181.

22 A. Portnov, The Holokaust in the Public Discourse of Post-Soviet Ukraine, [w:] War and Memory in Russia, Ukraine and Belarus, red. J. Fedor i in., London 2017, s. 347-350.

23 W 2006 Rada Najwyższa Ukrainy uznała, że Hołodomor był genocydem ukraińskiego narodu. Na przestrzeni kilku lat taką interpretację przyjęło oficjalnie kilkanaście państw. Strona izraelska kwestionowała nie tylko moralne i definicyjne ograniczenia użycia tego sformułowania, ale także wskazywała na konsekwencje w zakresie prawa międzynarodowego uznania Hołodomoru za genocyd. $\mathrm{Na}$ temat głodu na Ukrainie i jego recepcji szerzej: A. Applebaum, Czerwony gtód, przeł. B. Gadomska, W. Gadomska, Warszawa 2018; W. Kudela-Świątek, Miejsca (nie)pamięci. O upamiętnianiu ukraińskiego Wielkiego Gtodu z lat 1932-1933, Kraków 2014. 
noetnicznego obrazu historii stało się jednak dalsze „pielęgnowanie” obojętności na dyskusję o Holokauście i ukraińskim antysemityzmie. Gestem odbieranym jako antyżydowski było opublikowanie w 2008 r. listy nazwisk osób odpowiedzialnych za Głód 1933-1934, na której znaleźli się głównie Żydzi i Łotysze, oraz nobilitowanie środowisk związanych z weteranami OUN-UPA i ogłoszenie w 2010 r. jej liderów, Stepana Bandery i Romana Szuchewycza, bohaterami Ukrainy ${ }^{25}$.

Prezydent Janukowycz powrócił do retoryki Leonida Kuczmy, czego przykładem było przemówienie z okazji 70. rocznicy zbrodni w Babim Jarze, w którym znów mówił o zbrodniach przeciwko ludności cywilnej, nie wspominając konkretnie o Żydach i Szoah. Wkrótce po zainaugurowaniu prezydentury, w kwietniu 2010 r., sąd okręgowy w Doniecku uchylił dekret Juszczenki dotyczący Bandery, co wyraźnie pokazało różnice pomiędzy środowiskiem politycznym nowego prezydenta a obozem narodowo-nacjonalistycznym, związanym z poprzednim prezydentem.

„Rewolucja godności” z lat 2014-2015 była starciem dwóch modeli narracji historycznej. Środowiska osób związanych z Janukowyczem, Partią Regionów i komunistami nazywały zwolenników przemian „banderowcami” i „faszystami”, przestrzegając przed nacjonalizmem. Po odsunięciu Janukowycza nowa elita władzy już w kwietniu 2015 r., niejako w kontrze do tej retoryki, zdecydowała o wprowadzeniu ustawy O prawnym statusie i poszanowaniu pamięci bojowników o niezależnośc Ukrainy $w X X$ wieku ${ }^{26}$, zrównującej status weteranów OUN-UPA i Armii Czerwonej.

\section{DYSKURSY I MODELE}

Historyk Anatolij Podolskyj wskazał na trzy możliwe scenariusze narracji o Holokauście, które mogą być obecne w polityce historycznej Ukrainy:

1. Model narracji neoradzieckiej - Żydzi ukraińscy byli ofiarami nazistów (w narracji politycznej „faszystów”) oraz ukraińskich nacjonalistów, a ten, kto przeżył - ocalał tylko dzięki Armii Czerwonej, wyzwalającej Ukrainę od Niemców i ich sojuszników.

2. Model narracji nacjonalistycznej - ofiary Holokaustu to ofiary III Rzeszy, naród ukraiński ma szanować pamięć o Żydach, w pierwszej kolejności wspominając jednak tych, którzy ratowali Żydów, stając się Sprawiedliwymi wśród Narodów Świa$\mathrm{ta}^{27}$. W tym modelu ukraińscy nacjonaliści nie mieli nic wspólnego z eksterminacją Żydów.

3. Model liberalny - Holokaust to część historii nazistowskiej okupacji Ukrainy i II wojny światowej w Europie oraz historii Ukrainy XX w., dlatego należy badać

25 Protest wystosowały środowiska żydowskie w Ameryce, m.in. Liga przeciw Zniesławieniu.

26 Про правовий статус та вщанування пам'sті бориів за незалежність Украӥни у XX столітті, Ustawa Rady Najwyższej z 9 kwietnia 2015 r.

27 Ukraina ma odnotowanych 2659 Sprawiedliwych wśród Narodów Świata (czwarta pozycja wśród wszystkich państw), Names of Righteous by Country, Yad Vashem. The World Holokaust Remembrance Center, [online] https://www.yadvashem.org/righteous/statistics.html, 17 XI 2020. 
i wyjaśniać wszystkie historyczne aspekty Holokaustu ${ }^{28}$. Ten model wpisywałaby się w obywatelski projekt budowania tożsamości Ukraińców uwzględniający jej skompilowaną przeszłość i kulturę.

Podolskyj twierdzi, że niedostatek opracowań i rzetelnego podejścia do tematu stosunku Ukraińców do Żydów jest związany z niechęcią środowiska naukowego do przedstawiania Ukrainy jako kraju o złożonej historii etnicznej, zwłaszcza jeśli jej ważną częścią składową ma być historia relacji ukraińsko-żydowskich. Po rozpadzie ZSRR zainteresowanie tematyką Holokaustu wyrażenie wzrosło, ale według Podolskiego to i tak zbyt mało jak na skalę ofiar ${ }^{29}$. Jego zdaniem historia Ukrainy jest opowieścią o „Innym-obcym", z którym mentalnie nie odczuwa się wspólnoty dziejów, a dużo trudniej rozważać losy „Innego-naszego”, który był częścią społeczeństwa i zamieszkiwał te same ziemie. Bardziej komfortowo jest mówić „o nas” i „o nich”, „o naszym Głodzie” i „o ich Holokauście”30. Tym samym na Ukrainie formuluje się model „monokulturowej” pamięci historycznej, w którym Holokaust ukraińskich Żydów to fakt niemający związku z narodową historią Ukraińców, a pamięć o nim ma należeć raczej do kategorii (modelu) pamięci niewielkiej grupy etnicznej.

Małe zainteresowanie państwa polityką pamięci w zakresie Holokaustu powoduje upowszechnianie się opinii, że upamiętnianie i edukacja na temat zagłady Żydów leży w gestii zainteresowanej tym grupy, tym bardziej że dysponuje ona, w powszechnym mniemaniu, odpowiednimi zasobami materialnymi. Państwo scedowało powyższe kwestie na organizacje pozarządowe i inicjatywy społeczne. Aktywną pracę nad pamięcią o Holokauście prowadzą środowiska związane z Żydami ukraińskimi w kraju i diasporze. Centralnym ośrodkiem kultury żydowskiej na Ukrainie (nazywanym nawet „stolicą” ukraińskich Żydów, choć historycznie być może powinno być to jedno z miast Galicji) stał się Dniepr (Dniepropietrowsk). Oligarchowie pochodzenia żydowskiego ${ }^{31}$ zainwestowali w budowę największego w Europie żydowskiego kompleksu budynków „Menora”. Gmach przypomina menorę i mieści hotel, restauracje z koszernymi posiłkami, sale konferencyjne, szpital, synagogę. W Dnieprze działa też Centrum Studiów nad Holokaustem i Historią Żydów „Tkuma”. Instytucje badawcze funkcjonują również w Kijowie - Ukraińskie Centrum Badań nad Holokaustem oraz Centrum Studiów Historii i Kultury Żydów Europy Środkowej i Wschodniej przy Akademii Kijowsko-Mohylańskiej. Po 1991 r. powstało także kilka ważnych muzeów: Muzeum Historii Holokaustu w Charkowie (1996), Muzeum Holokaustu w Odessie (2009) oraz otwarte w 2013 r. w Dniepropietrowsku (dziś Dnieprze) Muzeum Historii Narodu Żydowskiego i Holokaustu, wzorowane na muzeach w Waszyngtonie i Yad Vashem w Jerozolimie.

28 А. Подольский, Сучасна історія як інструмент політичних маніпуляијй (на прикладі вивчення історії Голокосту), „Наукові записки” 2017, вип 4(90), s. 209. Wcześniej podobne modele narracji wyszczególniał J. Hrycak, Stosunki ukraińsko-żydowskie..., s. 109-112.

А. Подольский, Сучасна історія..., s. 207.

А. Подольский, Украинское общество и памлть о Холокосте: попььтка анализа некоторых acnектов, „Евроазиатский еврейский ежегодник”2008,5768 (2007/2008), [online] https://archive. jpr.org.uk/object-ukr45, 18 XI 2020.

31 Ihor Kołomojski, Hennadij Bogolubow. 
Należy jednak podkreślić, że są to inicjatywy samej społeczności żydowskiej. Jednym z nielicznych projektów, w którym partycypował budżet miasta, była koncepcja zagospodarowania pożydowskiej części ośrodka o nazwie „Przestrzeń Synagog”32, otwarta we Lwowie w $2016 \mathrm{r}$.

Staraniem Żydowskiego Forum Ukrainy Rada Najwyższa Ukrainy w 2011 r. przyjęła postanowienie o corocznym upamiętnianiu Międzynarodowego Dnia Pamięci Ofiar Holokaustu (27 stycznia). Fundacje i organizacje żydowskie przyczyniły się też do uporządkowania i oznaczenia licznych miejsc, gdzie mordowano Żydów. Dzięki funduszom amerykańskim, niemieckim i żydowskim upamiętniono Żydów w Czerniowcach (2016) oraz licznych miastach obwodu wołyńskiego, rówieńskiego, odeskiego.

Od czasów prezydentury Juszczenki toczy się dyskusja nad charakterem upamiętnienia i narracji muzealnej w Babim Jarze, ale dopiero w 2015 r. formalnie przekazano budynki, które mógłby pomieścić muzeum. Swobodne stawianie pomników, płyt i obelisków przez ostatnie dziesięciolecia spowodowało, że obecnie w Babim Jarze można naliczyć około trzydziestu różnych upamiętnień, co powoduje dezorientację i chaos narracyjny. W 2020 r. starły się różne koncepcje formuły muzealnej, do czego doszedł zarzut o niebezpieczeństwie współtworzenia narracji przez środowisko żydowskie związane z Rosją, co może źle wróżyć projektowi i oddalać perspektywę otwarcia memoriału.

Model pamięci „wielokulturowej” reprezentowany jest przez organizacje społeczne, tzw. liberalnych historyków ukraińskich, niektórych naukowców z diaspory ukraińskiej, a także badaczy europejskich ${ }^{33}$. Takie podejście ukazuje Żydów jako część narodu ukraińskiego, a ich historię jako część przeszłości Ukrainy. Publikacje naukowe to najczęściej niezależne od państwa periodyki. System edukacji o Holokauście jest realizacją polityki historycznej państwa w tym zakresie. O ile w sowieckich podręcznikach problem Holokaustu był całkowicie pomijany, o tyle program nauki historii przewiduje godzinę lekcyjną o Holokauście w ramach zajęć o "nazistowskim systemie okupacyjnym w Europie”. W 2000 r. Ukraina uczestniczyła w Konferencji w Sztokholmie i dołączyła do deklaracji o ochronie pamięci o Holokauście we współczesnym świecie. Problem ten pojawia się też na egzaminach kończących szkołę średnią. Formalnie zatem Ukraina wypełnia lukę edukacyjną, jednak niewielka ilość czasu poświęcona na tę tematykę oraz wpisanie tematu w ogólnoeuropejski kontekst bez właściwego osadzenia go w historii narodowej i lokalnej powoduje, że Holokaust jest praktycznie nieobecny w edukacji szkolnej. Ukraiński kontekst Zagłady pozostaje nadal mało znany społeczeństwu, zwłaszcza młodzieży.

32 Fundusze pochodziły także z Niemieckiego Towarzystwa Współpracy Międzynarodowej (GIZ), fundacji izraelskich i amerykańskich. „Przestrzeń Synagog” można obejrzeć na stronie lwowskiego Centrum Miejskiej Historii: [online] https://www.lvivcenter.org/public/spatial/space-of-synagogues/, 20 XI 2020.

33 Ukraińskie Centrum Studiów nad Holokaustem i Historią Żydów „Tkuma” w Dnieprze, Ukraińskie Centrum Badań nad Holokaustem w Kijowie, czasopismo „Krytyka”, Komitet „Babi Jar”, Związek Nauczycieli Historii „Nowa Doba”. Zob. J.P. Himka, The Reception..., s. 626-652. 
Badania przeprowadzone przez Elenę Iwanową na grupie 237 studentów z Charkowa, Połtawy i Lwowa ujawnity regionalną specyfikę kolektywnej pamięci o Holokauście $^{34}$. Studenci z Lwowa czterokrotnie częściej niż studenci z Połtawy i dziesięciokrotnie częściej niż studenci z Charkowa wykorzystywali regionalny dyskurs, a ich pamięć była bardziej nasycona ukraińskimi faktami i odnosiła się do Holokaustu na Ukrainie. Niewielu studentów z Połtawy i Charkowa wspominało o kontekście regionalnym, co oznacza myślenie o zagładzie Żydów jako „obcym” wydarzeniu, wyłączonym z ukraińskiej historii i pamięci. W latach 2003-2017 zaobserwować można zwiększone zainteresowanie tematyką wśród młodych naukowców. W tym okresie powstały liczne prace doktorantów opisujące Holokaust w różnych ukraińskich regionach ${ }^{35}$.

\section{WNIOSKI}

Na zachodzie Europy zainteresowanie własną przeszłością i pamięcią zaowocowało instytucjonalizacją pamięci. W krajach byłego ZSRR proces odkrywania tematów wcześniej zakazanych zderzył się koniecznością stworzenia narracji narodowych, co powodowało wybiórcze i instrumentalne traktowanie historii, zwłaszcza w jej trudnych i niejednoznacznych interpretacyjnie zakresach.

Ważnym elementem tożsamości historycznej Ukraińców jest II wojna światowa. Jednak obraz całego pokolenia okazał się całkowicie zafałszowany przez radziecką propagandę, co do dziś oddziałuje na zbiorową świadomość i modele narracji. Jak pisał Jarosław Poliszczuk, pokolenie wojenne zostało zlikwidowane fizycznie i symbolicznie przez zakłamanie historii ${ }^{36}$. Sami bohaterowie stali się źródłem zakłamanej narracji i tworzyli wypaczoną postpamięć swych potomków, w której brakowało miejsca na opowieść o Holokauście, zbrodniach, narracje mniejszościowe na rzecz opowieści o zbiorowej chwale i zwycięstwie. Dynamiczna pamięć o Holokauście, nazwana przez Mariannę Hirsch postpamięcią, uwarunkowana jest na Ukrainie komunistyczną przeszłością. Pokolenie, które powinno tworzyć postpamięć, doświadczyło wykluczenia z możliwości uczestniczenia w tym procesie. Dla dzieci osób ocalonych z Zagłady niedostępne są miejsca z opowieści rodziców i dziadków. Powodem jest nie tylko emigracja, ale także fakt, że miejsca związane ze zbrodniami na Żydach zostały w przestrzeni radzieckiej skrzętnie zakamuflowane, zniszczone, zmienione, a pamięć o nich „wygnana" ${ }^{37}$. W okresie poradzieckim „poholokaustowa topografia" ${ }^{38}$ nie została na Ukrainie dostrzeżona i właściwie upamiętniona, czego przykładem jest choćby Babi Jar.

34 Е. Иванова, Региональньце особенности коллективной памяти студентов о Холокосте в современной Украине, „Голокост і сучасність” 2008, nr 2(4), s. 9-28.

35 Takich prac w latach 2003-2015 powstało około 10.

36 J. Poliszczuk, Mapa pamięci w ujęciu pokoleniowym: wymiar ukraiński, [w:] Świadectwo pamięci. W kregu źródet i dyskursów (od XIX wieku do dzisiaj), red. E. Dąbrowicz, B. Larenta, M. Domurad, Białystok 2017, s. 360 .

37 M. Hirsch, Past Lives. Postmemories in Exile, „Poetics Today” 1996, vol. 17, nr 4, s. 662.

38 Szerzej o krajobrazach pamięci: A. Szczepan, Krajobrazy pamięci, „Teksty Drugie” 2014, nr 1, s. 103126. 
Potomkowie Żydów na Ukrainie doświadczyli też wykluczenia innego rodzaju - żydowska tożsamość pozostawała często rodzinnym sekretem. Przestrzeń topograficzna i mentalna dla postpamięci o Holokauście na Ukrainie była i jest ograniczona. Przyczynił się do tego najpierw system komunistyczny, który tworząc metanarrację o „radzieckości', unikał określania narodowości ofiar, a po 1991 r. - ukraińska polityka historyczna, niesprzyjająca wpisywaniu modeli pamięci narodowych do głównego nurtu narracji historycznej.

$\mathrm{Na}$ Ukrainie wyróżnia się dwa zasadnicze modele pamięci: nacjonalistyczny i postsowiecki. Frakcje polityczne będące przy władzy przez ostatnie trzydziestolecie prezentowały różne podejścia do polityki historycznej" ${ }^{39}$, ale ani model postradziecki, ani narodowy/nacjonalistyczny nie sprzyjał rozwojowi dyskusji społecznej na temat Holokaustu, a wręcz go marginalizował. Historiografia ukraińska po 1991 r. dotycząca Holokaustu kształtowała się pod wpływem historiografii radzieckiej oraz emigracyjnej i miała charakter reaktywny wobec zarzutów o antysemickość Ukraińców. W nacjonalistycznym modelu pamięci nie ma przestrzeni dla pamięci o Holokauście na Ukrainie, polega on raczej na strategiach wypierania traum i win, ewentualnie podkreślaniu zasług Ukraińców w ratowaniu Żydów. Model postradziecki też obywa się bez narracji o Holokauście, choć raczej z powodu braku w ZSRR tradycji opisu wojny jako doświadczenia wieloetnicznego. W tym sensie oba modele są podobne - oba prowadzą do tworzenia monoetnicznej narracji i przyczyniają się do marginalizacji tematyki Zagłady. Dyskurs mniejszościowy (model etniczny) o Holokauście na Ukrainie dotychczas nie awansował do rangi narracji ogólnopaństwowej. Do tej pory tylko model pamięci etnicznej Tatarów krymskich wszedł do dyskursu ogólnopaństwowego, choć stało się to niejako niezależnie od wcześniejszych starań Tatarów - w związku z sytuacją polityczną po aneksji Krymu. Po 2014 r. dostrzega się jednak większą aktywność społeczną środowisk dążących do włączenia dyskusji o losach Żydów w czasie II wojny światowej w szerszy kontekst ukraińskiej narracji historycznej i kulturowej.

\section{BIBLIOGRAFIA}

Applebaum A., Czerwony gtód, przel. B. Gadomska, W. Gadomska, Warszawa 2018.

Assmann A., Pię́́strategii wypierania ze świadomości, przeł. A. Pełka, [w:] Pamięć zbiorowa i kulturowa. Wspótczesna perspektywa niemiecka, red. M. Saryusz-Wolska, Warszawa 2009.

Chwedoruk R., Polityka historyczna w Europie - periodyzacja i wiodace dyskursy, „Studia Politologiczne" 2015, vol. 35 .

39 О. Гриценко, Президенти і пам'sть. Політика пам'sті президентів України (1994-2014): nідгрунтя, послання, реалізаціяя, результати, Київ 2017; К. Jędraszczyk, Explicit and Implicit Meanings in the Historical Policies of Ukrainian Presidents in 1991-2010/ Явнье и скрытые смысль исторической политики украинских президентов в 1991-2010 годах, [w:] Explicit and Implicit Meanings of Cultural Communication / Явныье и скрьтыце смысль культурной коммуникации, red. К. Је̨draszczyk, Gniezno-Poznań 2015, s. 139-152. 
Derev'ânij I.Â., Duhovni ta moral'ni cinnosti v ekspozicï Nacional'nogo muzề-memorial pam'âti žertv okupacijnih režimiv „Tûrma na Lonc'kogo”, w: Nacional'na ta istorična pam'ât', zb. nauk. prac., vip. 4, Kiï 2012.

Golka M., Pamięć spoteczna i jej implanty, Warszawa 2009.

Gricenko O., Prezidenti i pam'ât'. Politika pam'âti prezidentiv Ukraïni (1994-2014): pidrruntâ, poslannâ, realizaciâ, rezul'tati, Kï̈ 2017.

Himka J.P., The Reception of the Holokaust in Postcommunist Ukraine, [w:] Bringing the Dark Past to Light: The Reception of the Holokaust in Postcommunist Europe, red. J.P. Himka, J.B. Michlic, Lincoln-London 2013, https://doi.org/10.2307/j.ctt1ddr8vf.

Hrycak J., Stosunki ukrainsko-żydowskie w postradzieckiej historiografii ukraińskiej, [w:] Historycy polscy i ukraińscy wobec problemów XX wieku, red. P. Kosiewski, G. Motyka, Kraków 2000.

Hrycak J., Ukraincy w akcjach antyżydowskich podczas II wojny światowej, [w:] J. Hrycak, Nowa Ukraina. Nowe interpretacje, Warszawa 2009.

Hirsch M., Past Lives. Postmemories in Exile, „Poetics Today” 1996, vol. 17, nr 4, https://doi. org/10.2307/1773218.

Ivanova E., Konstruirovanie kollektivnoj pamâti o Holokoste v Ukraine, „Ab Imperio” 2004, nr 2. Ivanova E., Regional'nye osobennosti kolektivnoj pamâti studentov o Holokauste v sovremennoj Ukraine, „Holokaust i sučasnist” 2008, nr 2(4), s. 9-28.

Jędraszczyk K. Explicit and Implicit Meanings in the Historical Policies of Ukrainian Presidents in 1991-2010/ Явнье и скрытые смысль исторической политики украинских президентов в 1991-2010 годаx, [w:] Explicit and Implicit Meanings of Cultural Communication/ Явныле и скрытыц смьсльь культурной коммуникации, red. K. Jędraszczyk, Gniezno-Poznań 2015.

Jones E., Żydzi Lwowa w okresie okupacji 1939-1945, przeł. z jęz. ros. W. Promińska, Łódź 1999.

Kalakura Â., Ukraïns'ka istoriografiâ, Kïv 2004.

Kas'ânov G., K probleme definicij: istoričeskaâ pamât', istoričeskaâ politika, [w:] Istoriâ, pam'ât', politika. Zb. naukovih statej, uporâd. G. Kas'ânov, O. Gajdaj, Kï̈ 2016.

Kas'ânov G., Past Continuous: Istorična politika 1980-h-2000-h: Ukarïna ta susidi, Kïv 2018.

Kawa M., Narracje o Holokauście. Dyskurs naukowy a debata publiczna w Polsce, Chełm 2017.

Krivošeâ V., Modeli pam'âti i deržavna politika pam'âti, [w:] „Nacional'na ta istorična pam'ât”" 2011, Vip. 1.

Kudela-Świątek W., Miejsca (nie)pamięci. O upamiętnianiu ukraińskiego Wielkiego Gtodu z lat 1932-1933, Kraków 2014.

Kula M., Amnezja - choroba tylko częściowo zawiniona, [w:] Wobec przesztości. Pamięćprzesztości jako element kultury wspótczesnej, red. A. Szpociński, Warszawa 2005.

Kula M., Między przesztościa a przysztościa. O pamięci, zapominaniu i przewidywaniu, Poznań 2004.

Kula M., Nośniki pamięci historycznej, Warszawa 2002.

Kul'čic'kij S., Golodomor v Ukraïni j ukraïns'kij Golokost, „Golokost i sučasnist'. Naukovij časopis Ukraïns'kogo centru vivčennâ istoriï Golokostu” 2008, nr 1(3).

Levitas F., Golokost: pam'ât', fakti, dokumenti, [w:] Kul'tura istoričnö̈ pamâti: cvropejs'kij ta ukraïns'kij dosvid, red. Û. Šapoval, Kiï 2013. 
Lustiger A., Czerwona księga. Stalin i Żydzi. Tragiczna historia Żydowskiego Komitetu Antyfaszystowskiego i radzieckich Żydów, przeł. E. Kaźmierczak, W. Leder, Warszawa 2004.

Matusiak A., Wyjść z milczenia. Dekolonialne zmagania kultury i literatury ukraińskiej XXI wieku z trauma posttotalitarna, Wojnowice-Wrocław 2019.

Michlic J.B., „Pamiętanie dla upamiętnienia”, „pamiętanie dla korzyści” i „pamiętanie, żeby zapomnieć”. Różne modele pamięci o Żydach i Zagtadzie w postkomunistycznej Polsce, „Kultura i Społeczeństwo” ” 2011, vol. 55, nr 4, https://doi.org/10.35757/KiS.2011.55.4.11.

Names of Righteous by Country, Yad Vashem. The World Holokaust Remembrance Center, [online] https://www.yadvashem.org/righteous/statistics.html, 17 XI 2020.

Podol'skij A., Sučasna istoriâ âk instrument političnih manipulâcij (na prikladi vivčennâ istoriï Golokostu), „Naukovi zapiski” 2017, vip 4(90).

Podol's'kij A., Tema Golokostu v sučasnij ukraïns'kij istoriografii: problemi naukovih doslidžen' ta interpretacij, [w:] Druga svitova vijna i dolâ narodiv Ukraïni: Materiali Vseukraïns'koï naukovoï konferenciï, Kiïv 2005.

Podol'skij A., Ukrainskoe obŝestvo i pamât' o Holokoste: popytka analiza nekotoryh aspektov, „Evroaziatskij evrejskij ežegodnik” 2008, 5768 (2007/2008), [online], https://archive.jpr. org.uk/object-ukr4, 18 XI 2020.

Politična istoriâ Ukraïni. XX stolittâ: Ukraïna v roki Drugoï svitovoï vijni (1939-1945), pedkol, I. F. Kuras (golova) ta in, U 6, t. 4, Kiïv 2003.

Poliszczuk J., Mapa pamięci w ujęciu pokoleniowym: wymiar ukrainski, [w:] Świadectwo pamięci. Wręgu źródet i dyskursów (od XIX wieku do dzisiaj), red. E. Dąbrowicz, B. Larenta, M. Domurad, Białystok 2017.

Portnov A., The Holokaust in the Public Discourse of Post-Soviet Ukraine, [w:] War and Memory in Russia, Ukraine and Belarus, red. J. Fedori i in., London 2017, https://doi. org/10.1007/978-3-319-66523-8.

Pro pravovij status ta všanuvannâ pam 'âti borciv za nezaležnist' Ukraïni u XX stolitti, Ustawa Rady Najwyższej z 9 kwietnia 2015 r.

Redlich S., Moralność i rzeczywistość. Metropolita Andriej Szeptycki i Żydzi w czasach Holokaustu i II wojny światowej, „Zagłada Żydów. Studia i Materiały” 2008, nr 4, https://doi. org/10.32927/ZZSiM.273.

Ricœur P., Pamięć, historia, zapomnienie, przeł. J. Margański, Kraków 2006.

Szczepan A., Krajobrazy pamięci, „Teksty Drugie” 2014, nr 1.

Ukraïna: politična istoriâ 20 - počatok 21 stolittâ, Kiì 2007.

Ukraïns'kij Golokost 1932-1933. Svidčennâ tih, hto viživ, Kerivnik proektu o. Urij Micik, t. 6, Kiiv 2008.

Żakowski J., Rewanż pamięci, Warszawa 2002.

Гриценко О. Президенти і пам'ять. Політика пам'яті президентів Украӥни (1994-2014): підгрунтя, послання, реалізауія, результати, Київ 2017.

Аерев'яний І.Я., Ауховні та моральні цінності в єкспозицї Національного музею-меморіал пам'sті жертв окупаційних режимів „Тюрма на Аонцького”, [w:] Науиональна та історична пам'smь, зб. наук. прац., вип. 4, Київ 2012. 
Иванова Е., Конструирование коллективной памяти о Холокосте в Украине, „Аb Imperio” 2004, nr 2.

Иванова Е., Региональныц особенности коллективной памяти студентов о Холокосте в современной Украине, „Голокост і сучасність” 2008, nr 2(4), s. 9-28.

Камакура Я., Українська історіографія, Київ 2004.

Касьянов Г., К проблеме дефиничий: историческая память, историческая политика, [w:] Г. Касьянов, О. Гайдай, Iсторія, пам’ять, політика, 36. наукових статей, упоряд, Київ 2016.

Касьянов Г., Past Continuous: Icmoрична політика 1980-x-2000-x: Укарїна та сусиди, Київ 2018.

Кривошея В., Моделі пам’smi i державна політика пам’smi, „Національна та історична пам'ять" 2011, Вип. 1.

Кульчицький С., Голодомор в Украӥні й украӥнський Голокост, „Голокост і сучасність. Науковий часопис Українського центру вивчення історії Голокосту” 2008, nr 1(3).

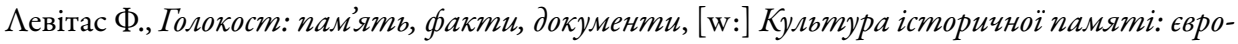
пейський та украӥнський досвід, реА. Ю. Шаповац, Київ 2013.

Подольский А., Сучасна історія як інструмент політичних маніпулячій (на прикладі вивчення історї Голокосту), „Наукові записки” 2017, вип 4(90).

Подольский А., Украинское общество и памлть о Холокосте: попьтка анализа некоторыхх аспектов, „Евроазиатский еврейский ежегодник” 2008, 5768 (2007/2008), [online] https://archive.jpr.org.uk/object-ukr4, 18 XI 2020.

Подольський А., Тема Голокосту в сучасній украйнській історіографї̈: проблеми наукових досліджень та інтерпретацій, [w:] Аруга світова війна і доля народів України: Матеріали Всеукраїнської наукової конференцї, Київ 2005.

Політична історія Украӥни. ХХ столітmя: Украйна в роки Аругої світової війни (19391945), редкол, І. Ф. Курас (голова) та ін, У 6, т. 4, Київ 2003.

Про правовий статус та вшанування пам'яті бориів за незалежність Украйни у XX столітmi, Ustawa Rady Najwyższej z 9 kwietnia 2015 r.

Україна: політична історія 20 - початок 21 століття, Київ 2007.

Український Голокост 1932-1933. Свідчення тих, хто вижив, Том 6, Керівник проекту о. Юрій Мицик, Київ 2008.

dr Katarzyna JĘDRASZCZYK - adiunkt w Instytucie Kultury Europejskiej Uniwersytetu im. A. Mickiewicza w Zakładzie Badań nad Tożsamością Kulturową. Doktor nauk humanistycznych w dziedzinie historii. Autorka i redaktorka monografii oraz artykułów poświęconych współczesnym stosunkom ukraińsko-polskim, Cerkwi prawosławnej oraz polityce historycznej Ukrainy. W swojej książce pt. Strategiczne partnerstwo ukrainsko-polskie. Polska w polityce niepodlegtej Ukrainy (2010) opisała m.in. ukraińską perspektywę sporów historycznych o Cmentarz Orląt we Lwowie i upamiętnianie rocznic Wołynia 1943. Odbyła staże na uniwersytetach w Kijowie, Charkowie, Lwowie, Tel Awiwie oraz Odessie. 